\title{
Mass Spectrometry Analyses of Rat 2b Myosin Heavy Chain Isoform
}

\author{
J. ŽURMANOVÁ ${ }^{1,2}$, D. MALÁČOVÁ ${ }^{1,2,}$, F. PƯTA $^{2}$, P. NOVÁK $^{3}$, J. ŘÍČNÝ ${ }^{1}$, \\ T. SOUKUP ${ }^{1}$
}

${ }^{1}$ Institute of Physiology, Academy of Science of the Czech Republic, ${ }^{2}$ Department of Physiology and Developmental Biology, Faculty of Science, Charles University, ${ }^{3}$ Institute of Microbiology, Academy of Science of the Czech Republic, Prague, Czech Republic

Received May 4, 2007

Accepted June 21, 2007

\begin{abstract}
Summary
We have separated $2 \mathrm{~b}$ myosin heavy chain (MyHC) isoform from the rat extensor digitorum longus muscle by SDSPAGE and analyzed it by two subsequent mass spectrometry techniques. After tryptic digestion, the obtained peptides were identified by Matrix-Assisted Laser Desorption/Ionisation reflectron Time of Flight mass spectrometry (MALDITOF MS) and sequenced by Liquid chromatography tandem mass spectrometry (ESI LC/MS/MS). The analyzed peptides proportionally covered $30 \%$ of the $2 \mathrm{~b}$ MyHC isoform sequence. The results suggest that the primary structure is identical with the highest probability to a NCBI database record ref|NP_062198.1|, representing the last updated record of rat $2 \mathrm{~b}$ isoform. Nonetheless, four peptides carrying amino acid substitution(s) in comparison with the NCBI database record were identified.
\end{abstract}

\section{Key words}

Rat muscle myosin • Myosin heavy chain $2 \mathrm{~b}$ isoform • MALDI TOF mass spectrometry $\bullet$ ESI LC/MS/MS mass spectrometry

Myosin heavy chain (MyHC) cDNA sequences are highly conserved among mammals including human, mouse and rat. Although the full sequences of human and mouse type 1, 2a, 2x/d and 2b MyHC isoforms have been described, the information for rat is still incomplete and often controversial, especially for the $2 b$ isoform. When we started our experiments (2005), the NCBI database record contained only gi|34870888|ref|XP_340819.1|, annotated as "similar to MyHC 2b" and supposed to be a product of a splicing variant of Myh 4 gene. On the other hand, when we compared the primers used in RT-PCR studies of rat muscles (Mc Nally et al. 1989, DeNardi et al. 1993, Lieber et al. 1993, Jaschinski et al. 1998) with the available database information, we found that primers used for $2 b$ isoform corresponded not only to the $2 b$-like isoform, but also to the sequence annotated as "catenin". In order to obtain more reliable data about the primary structure of MyHC $2 b$ in the rat (useful for construction of new primers, as well), we have separated $2 \mathrm{~b}$ MyHC isoform from the rat EDL muscle by SDS-PAGE (Fig.1) and analyzed it by two subsequent mass spectrometry techniques (MS). 


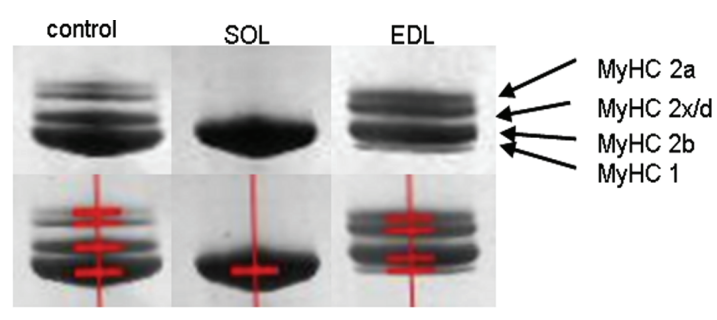

Fig. 1. SDS-PAGE separation of MyHC isoforms from 8-month-old female Lewis rat. SOL- soleus muscle, EDL- extensor digitorum longus muscle, control: SOL+EDL.

The separated 2b MyHC isoform bands (Fig.1) were stained by CBB-R 250 and stained protein bands were cut from the gel and washed several times with $10 \mathrm{mM}$ dithiothreitol (DTT), $0.1 \mathrm{M}$ 4-ethylmorpholine acetate $(\mathrm{pH} 8.1)$ in $50 \%$ acetonitrile $(\mathrm{MeCN})$. After the complete destaining, the gel was incubated with $60 \mathrm{mM}$ iodoacetamide for $30 \mathrm{~min}$ at RT in dark, washed with water, shrunk by dehydration with $\mathrm{MeCN}$ and reswollen in water. Next, the gel was partly dried using a SpeedVac concentrator and then reconstituted with cleavage buffer containing $0.01 \%$ 2-mercaptoethanol, $0.1 \mathrm{M}$ 4-ethylmorpholine acetate, $10 \% \mathrm{MeCN}$ and sequencing grade trypsin (Promega, $5 \mathrm{ng} / \mu \mathrm{l}$ ). Proteolytic digestion was carried out overnight at $37^{\circ} \mathrm{C}$; the resulting peptides were extracted with $30 \% \mathrm{MeCN} / 1 \%$ formic acid and subjected to the two following MS analyses: A) Mass spectra were measured on a matrix-assisted laser desorption/ionisation reflectron time-of-flight MALDITOF mass spectrometer BIFLEX II (Bruker-Franzen, Bremen, Germany) equipped with a nitrogen laser $(337 \mathrm{~nm})$ and gridless delayed extraction ion source. Ion acceleration voltage was $19 \mathrm{kV}$ and reflectron voltage was set to $20 \mathrm{kV}$. The spectra were calibrated externally using the monoisotopic $[\mathrm{M}+\mathrm{H}]^{+}$ion of peptide standard somatostatin (Sigma). The saturated solution of $\alpha$-cyano4-hydroxy-cinnamic acid in $50 \% \mathrm{ACN} / 0.2 \%$ TFA was then used as a MALDI matrix. One $\mu \mathrm{l}$ of matrix solution was mixed with $1 \mu \mathrm{l}$ of the sample on the target and the droplet was allowed to dry at ambient temperature. B) Tryptic peptide mixture was applied on the MagicC18 column, $0.2 \times 150 \mathrm{~mm}, 200 \AA, 3 \mu \mathrm{m}$ (Michrom Bioresources, $\mathrm{CA}$ ) and separated using gradient elution: $10 \mathrm{~min}$ from $5 \% \mathrm{MeCN} / 0.5 \%$ acetic acid to $15 \%$ $\mathrm{MeCN} / 0.4 \%$ acetic acid, $40 \mathrm{~min}$ from $15 \% \mathrm{MeCN} /$ $0.5 \%$ acetic acid to $40 \% \mathrm{MeCN} / 0.4 \%$ acetic acid and 10 min from $40 \% \mathrm{MeCN} / 0.5 \%$ acetic acid to $95 \%$ $\mathrm{MeCN} / 0.4 \%$ acetic acid at flow rate $4 \mu \mathrm{l} / \mathrm{min}$. The column was connected to a $\mathrm{LCQ}^{\mathrm{DECA}}$ ion trap mass spectrometer (ThermoQuest, San Jose, CA) equipped

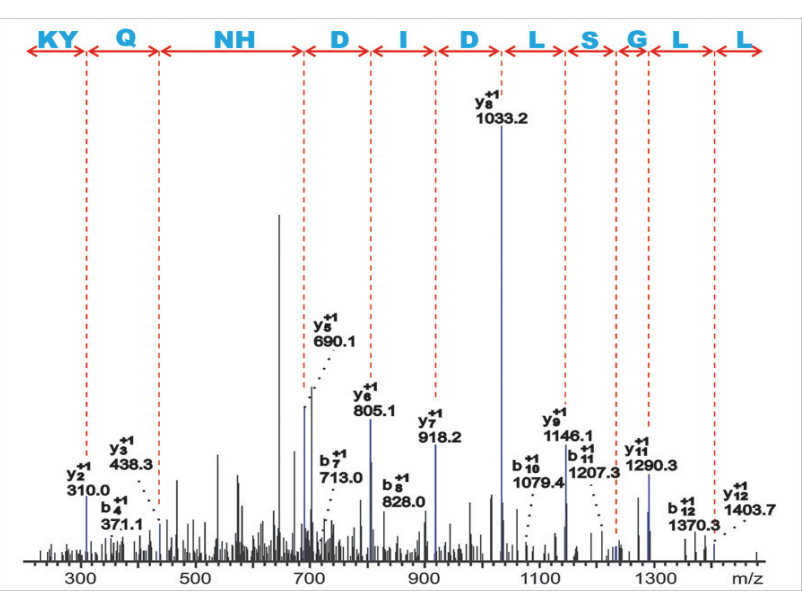

Fig. 2. The fragment spectrum of a tryptic peptide demonstrating the single amino acid mutation $\mathrm{T}>\mathrm{N}$ of the rat $2 \mathrm{~b}$ $\mathrm{MyHC}$ isoform sequence.

with a nanoelectrospray ion source (ESI LC/MS/MS). Spray voltage was held at $1.8 \mathrm{kV}$, tube lens voltage was $-10 \mathrm{~V}$. The heated capillary was kept at $150{ }^{\circ} \mathrm{C}$ with a voltage of $32 \mathrm{~V}$. Collision energy was kept at 42 units and the activation time was $30 \mathrm{~ms}$. Collisions were done from the first intense ion in each chromatographic peak and every 2 scans were accumulated. Positive-ion full scan and CID mass spectra were recorded. Full scan spectra were acquired over $\mathrm{m} / \mathrm{z}$ range $350-1600$ and selected spectra were interpreted by SEQUEST software in order to assign the peptide fragment spectra.

As example, the fragment spectrum of a tryptic peptide demonstrating the single amino acid mutation $\mathrm{T}>\mathrm{N}$ in the rat $2 \mathrm{~b}$ MyHC isoform sequence is shown in Figure 2. All peptides analyzed by MALDI-TOF and ESI LC/MS/MS (highlighted by colors in Fig. 3) were compared with database records of $\mathrm{MyHC}$ isoform variants using Multiple sequence alignment (CLUSTAL W 1.83, Higgins et al. 1994). The ref|NP_062198.1| was identified as the most likely variant of the rat $2 b \mathrm{MyHC}$ isoform. Both analyses have identified eight peptides specific for rat $2 \mathrm{~b}$ MyHC (marked in red) and 35 peptides not specific only for the $2 \mathrm{~b}$ MyHC isoform (marked in blue). They covered approximately $30 \%$ of the $2 \mathrm{~b}$ MyHC sequence. MALDI-TOF identified with high probability the presence of 19 peptides (non-underlined), four of them were $2 b$ isoform specific (non-underlined red). ESI LC/MS/MS technique has confirmed the existence of 24 peptides (underlined), four of them specific to $2 \mathrm{~b}$ isoform (underlined red). Furthermore, the latter technique has revealed presence of five peptides, whose primary structures differ from their database counterparts (Fig. 3 bottom, in green, the differing amino acids are 
MSSDAEMAVFGEAAPYLRKSEKERIEAQNKPFDAKSSVFVVDAKESYVKATVQSREGGKV TAKTEGGATVTVKEDQVFSMNPPKYDKIEDMAMITHLHEPAVLYNLKERYAAWMIYTYSG LFCVTVNPYKWLPVYNPEVVAAYRGKKRQEAPPHI FS ISDNAYQFMLTDRENQSILITGE SGAGKTVNTKRVIQYFATIAVTGDKKKEEAPSGKMQGTLEDQI I SANPLLEAFGNAKTVR NDNSSRFGKF IRIHFGATGKLASADIETYLLEKSRVTFQLKAERSYHIFYQVMSNKKPEL IEMLLITTNPYDFAYVSQGEITVPS IDDQEELMATDTAVDILGFTADEKVAIYKLTGAVM HYGNMKFKQKQREEQAEPDGTEVADKAAYLTSLNSADLLKALCYPRVKVGNEYVTKGQTV QQVYNSVGALAKAMYEKMFLWMVTRINQQLDTKQPRQYFIGVLDIAGFEIFDFNTLEQLC INFTNEKLQQFFNHHMFVLEQEEYKKEGIEWEF IDFGMDLAACIELIEKPMGI FS ILEEE CMFPKATDTSFKNKLYEQHLGKSNNFQKPKPAKGKAEAHFSLVHYAGTVDYNI I GWLDKN KDPLNETVVGLYQKSGLKTLAFLFSGGQAAEAEGGGGKKGGKKKGSSFQTVSALFRENL $\bar{N}$ KLMTNLKSTHPHFVRCLI PNETKTPGAMEHELVLHQLRCNGVLEGIRICRKGFPSRILYA DFKQRYKVLNASA I PEGQF IDSKKASEKLLGS IDIDHTQYKFGHTKVFFKAGLLGTLEEM RDEKLAQLITRTQAVCRGYLMRVEFRKMMERRESIFCIQYNVRAFMNVKHWPWMKLYFKI KPLL KSAETEKEMATMKEDFEKAKEDLAKSEAKRKELEEKMVALMQEKNDLQLQVQAEAD GLADAEERCDQLIKTKIQLEAKI KELTERAEDEEEINAELTAKKRKLEDECSELKKDIDD LELTLAKVEKEKHATENKVKNLTEEMAGLDENIVKLTKEKKALQEAHQQTLDDLQAEEDK VNTLTKAKTKLEQQVDDLEGSLEQEKKLRMDLERAKRKLEGDLKLAQESTMDIENDKQQL DEKLKKKEFEMSNLQSKIEDEQALGMQLQKKI KELQARIEELEEEIEAERASRAKAEKQR SDLSRELEEISERLEEAGGATSAQIEMNKKREAEFQKMRR DLEEATLQHEATAAALRKKH ADSVAELGEQIDNLQRVKQKLEKEKSELKMEIDDLASNMETVSKAKGNLEKMCRTLEDQL SEVKTKEEEQQRLINELSAQKARLHTESGEFSRQLDEKDAMVSQLSRGKQAFTQQIEELK RQLEEESKAKNALAHALQSARHD CDLLREQYEEEQEAKAELQRAMSKAN SEVAQWRTKYE TDAIQRTEELEEAKKKLAQR LQDAEEHVEAVNSKCASLEKTKQRLQNEVEDLMIDVERSN AACAALDKK QRNFDKVLAEWKQKYEETQAELEASQKESRSLSTELFKVKNAYEESLDQL ETLKRENKNLQQEISDLTEQIAEGGKHIHELEKIKKQIDQEKSELQASLEEAEASLEHEE GKILRIQLELNQVKSEIDRKIAEKDEEIDQLKRNHLRVVESMQSTLDAEIRSRRDALRIK KKMEGDLNEMEIQLNHANRQAAEAIRNLRNTQGMLKDTQLHLDDALRGQDDLKEQLAMVE RRANLMQAEIEELRASLEQTERSRRVAEQELLDASERVQLLHTQNTSLINTKKKLETDIS QIQGEMEDIVQEARNAEEKAKKAITDAAMMAEELKKEQDTSAHLERMKKNMEQTVKDLQH RLDEAEQLALKGGKKQIQKLEARVRELENEVENEQKRNIEAVKGLRKHERRVKELTYQTE EDRKNVLRLQDLVDKLQTKVKAYKRQAEEAEEQSNVNLAKFRKIQHELEEAEERADIAES QVNKLRVKSREVHTKVISEE

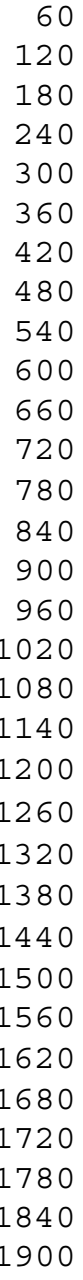

60

120

180

240

300

360

420

480

540

600

660

720

780

840

900

960

1020

1080

1140

1200

1260

1320

1380

1440

1500

1560

1620

1680

1720

1780

1840

1900

$\begin{array}{rlr}749 & \text { LLGSLDIDHNQYK } & 761 \\ 1181 & \text { DLEEATLQHEATAATLR } & 1197 \\ 1255 & \text { TLEDQLSEAR } & 1264 \\ 1401 & \text { LQDAEEAVEAVNAK } & 1414 \\ 1598 & \text { VVETMQSTLDAEIR } & 1611\end{array}$

Fig 3. The peptides obtained by trypsin cleavage of the rat EDL MyHC $2 b$ isoform band and determined by MALDI-TOF MS analysis are highlighted in colors and those peptides sequenced by subsequent $\mathrm{LCQ}^{\mathrm{DECA}} \mathrm{MS} / \mathrm{MS}$ analysis are underlined. These results are compared with database records of rat MyHC $2 \mathrm{~b}$ isoform variants using Multiple sequence alignment (CLUSTAL W 1.83, Higgins et al. 1994). The analyzed peptides revealed that the primary structure is highly identical with the NCBI database record ref|NP_062198.1| for the rat 2b MyHC isoform. Peptides specific for rat MyHC $2 b$ isoform are highlighted in red (A), peptides present also in other skeletal muscle MyHC isoforms are highlighted in blue (A), peptides with a point mutation according to (MS/MS) are shown in green (A) at the bottom (their database counterparts are marked by boxes), $\mathbf{X}$ - highlights point mutations revealed by ESI LC/MS/MS.

indicated by the yellow background).

MyHC $2 \mathrm{~b}$ isoform is contained in $2 \mathrm{~B}$ fibers which are the fastest from $2 \mathrm{~A}, 2 \mathrm{X} / \mathrm{D}$ and $2 \mathrm{~B}$ fast fiber types in the rat hind limb skeletal muscles (for review see Schiaffino and Reggiani 1996). In the rat EDL muscle, 2B fibers represent the most frequent fiber type (Soukup et al. 2002, Zachařová et al. 2005, Vadászová-Soukup et al. 2006). Interestingly, in human muscles, the $2 \mathrm{~B}$ fibers contain 2x/d MyHC isoform (Smerdu et al. 1994). Furthermore, the content of $2 \mathrm{~B}$ fibers and of $2 \mathrm{~b} \mathrm{MyHC}$ isoform is increased in the EDL muscles of hyperthyroid rats (Vadászová et al. 2006a,b, for review see Soukup and Jirmanová 2000). The knowledge of the complete primary structure of rat $2 \mathrm{~b}$ MyHC isoform could contribute to our understanding of physiological characteristics of this isoform. It could also be helpful for designing the most specific primers for (q)RT-PCR (Žurmanová et al. 2007). In conclusion, we have found eight peptides specific for $2 b$ isoform by MALDI-TOF analysis, four of them have been proved by ESI LC/MS/MS technique, as well. Furthermore, ESI LC/MS/MS analysis has revealed five peptides 
containing single amino acid substitution. Our data thus demonstrate that further detailed analysis is still necessary to describe the exact primary structure of the $2 \mathrm{~b}$ MyHC isoform of the rat.

\section{Acknowledgement}

Supported by MYORES No. 511978, MSMT CR LC554, GACR 304/05/0327 and 305/06/1115 grants and by the Research projects AV0Z 50110509 and AV0Z 5020051.

\section{References}

DENARDI C, AUSONI S, MORETTI P, GORZA L, VELLECA M, BUCKINGHAM M, SCHIAFFINO S: Type 2Xmyosin heavy chain is coded by a muscle fiber type-specific and developmentally regulated gene. $J$ Cell Biol 123: 823-835, 1993.

HIGGINS D, THOMPSON J, GIBSON T, THOMPSON JD, HIGGINS DG, GIBSON TJ, CLUSTAL W: Improving the sensitivity of progressive multiple sequence alignment through sequence weighting, position-specific gap penalties and weight matrix choice. Nucleic Acids Res 22: 4673-4680, 1994.

JASCHINSKI F, SCHULER M, PEUKER H, PETTE D: Changes in myosin heavy chain mRNA and protein isoforms of rat muscle during forced contractile activity. Am J Physiol 274: C365-C370, 1998.

LIEBER RL, BODINE SC, BURKHOLDER TJ, PIEROTTI DJ, RYAN AF: Cloning and in situ hybridization of type2A and type-2B rat skeletal muscle myosin tail region-implications for filament assembly. Biochem Biophys Res Commun 197: 1312-1318, 1993.

MCNALLY EM, KRAFT R, BRAVO-ZEHNDER M, TAYLOR DA, LEINWAND LA: Full length rat alpha and beta cardiac myosin heavy chain sequences: comparisons suggest a molecular basis for functional differences. J Mol Biol 210: 665-671, 1989.

SCHIAFFINO S, REGGIANI C: Molecular diversity of myofibrillar proteins: gene regulation and functional significance. Physiol Rev 76: 371-423, 1996.

SMERDU V, KARSCH-MIZRACHI I, CAMPIONE M, LEINWAND L, SCHIAFFINO S: Type IIx myosin heavy chain transcripts are expressed in type IIb fibers of human skeletal muscle. Am J Physiol 267: C1723-8, 1994.

SOUKUP T, JIRMANOVÁ I: Regulation of myosin expression in developing and regenerating extrafusal and intrafusal muscle fibres with special emphasis on the role of thyroid hormones. Physiol Res 49: 617-633, 2000.

SOUKUP T, ZACHAŘOVÁ G, SMERDU V: Fibre type composition of soleus and extensor digitorum longus muscles in normal female inbred Lewis rats. Acta Histochem 104: 399-405, 2002.

VADÁSZOVÁ A, HUDECOVÁ S, KRIŽANOVÁ O, SOUKUP T: Levels of myosin heavy chain mRNA transcripts and content of protein isoforms in the slow soleus muscle of 7-month-old rats with altered thyroid status. Physiol Res 55: 221-225, 2006a.

VADÁSZOVÁ A, HUDECOVÁ S, KRIŽANOVÁ O, SOUKUP T: Levels of myosin heavy chain mRNA transcripts and protein isoforms in the fast extensor digitorum longus muscle of 7-month-old rats with chronic thyroid status alterations. Physiol Res 55: 707-710, $2006 \mathrm{~b}$.

VADÁSZOVÁ-SOUKUP A, SMERDU V, ŽURMANOVÁ J, MALÁČOVÁ D, SOUKUP T: Unilateral foreign muscle transplantation has no effect on phenotype of unoperated rat muscles in long term experiments. Physiol Res 55: 49P, 2006.

ZACHAŘOVÁ G, VADÁSZOVÁ A, SMERDU V, ASMUSSEN G, SOUKUP T: The effect of a unilateral muscle transplantation on the muscle fiber type and the MyHC isoform content in unoperated hind limb slow and fast muscles of the inbred Lewis rats. Physiol Res 54: 691-696, 2005.

ŽURMANOVÁ J, MALÁČOVÁ D, PUTA F, ŘÍČNÝ J, SOUKUP T: Design of new primers for real time PCR of rat myosin heavy chain isoforms. Physiol Res 56: 42P, 2007.

\section{Corresponding author}

Tomáś Soukup, Institute of Physiology AS CR, Vídeňská 1083, CZ-142 20 Prague, Czech Republic. Fax: +420 24106 2488. E-mail: tsoukup@biomed.cas.cz 